\title{
TRANSLATING Kināyah can mawṣūf (METONYMY OF A MODIFIED OBJECT) IN SOME PROPHETIC HADITHS
}

\author{
Sahar Muhammed Ahmed Muhammed \\ Ph.D. student, Faculty of Arts, English Department, Helwan University \\ Assistant lecturer, Faculty of Arts, English Department, \\ Beni-Suef University
}

\begin{abstract}
The Prophetic Hadith (i.e. sayings of the Prophet) is full of rhetoric devices present throughout His sayings. One of the basic rhetorical devices is metonymy. Metonymy is a pervasive linguistic phenomenon in all cultures, in both spoken and written discourse. This paper investigates metonymy in Arabic language and its translation in general and assessing the translation of Kināyah 'an mawșūf (metonymy of a modified object) in Khan's translation (1997) of Șahihh Al-Bukhāri in particular. The distinctive style and the special nature of the Prophetic sayings make the translation of metonymy in the Prophetic Hadith stands as a challenging task for translators. Thus, the present study aims to arrive at the impact of translating metonymy in producing an effective language and the extent to which it is relayed accurately in the target language. The selected metonymies are extracted, analyzed and followed by the assessment of their translations. One of the purposes of the present research is to identify the extent to which metonymies in the Prophetic Hadith deepen their reading comprehension and investigate the strategies of translating metonymies of modified objects in the Prophetic Hadith. In order to observe the highly rhetorical style of Prophetic sayings and not to sacrifice part of their meaning, the source-oriented approach is recommended here in order to render the taste of the original culture and profound its values to the target reader.
\end{abstract}

Key Words:

Kināyah can mawșūf (metonymy of a modified object), the Prophetic Hadiths, Translation Studies, Source-Orientedness, Saḥ̆h̆ Al-Bukhārĭ. 
مجلة وادي النيل للاراسات والبحوث الإنسانية والاجتماعية والتربوية (مجلة علمية محكمة)

(ISSN : 2536 - 9555)

\section{ترجمة الكناية عن موصوف في بعض الأحاديث النبوية

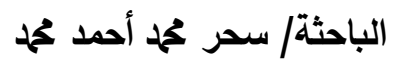

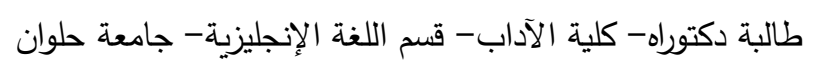

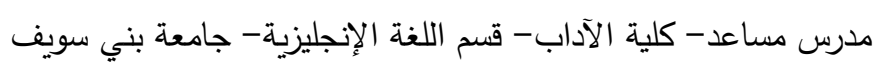

الملخص:

تثتمل الأحاديث النبوية علي العديد من الأساليب البلاغية، وتعد الكناية

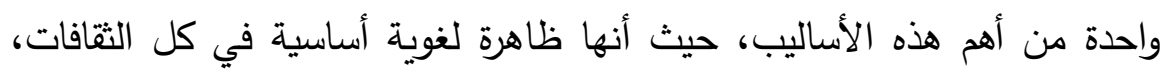

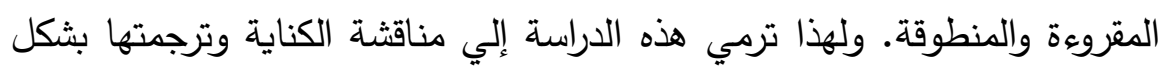
عام وإلي تقييم الكناية عن موصوف في الأحاديث النبوية في كتاب صحيح

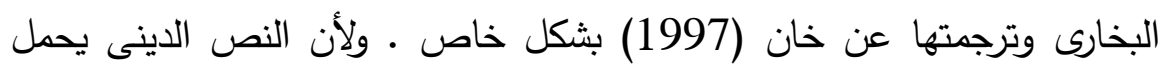

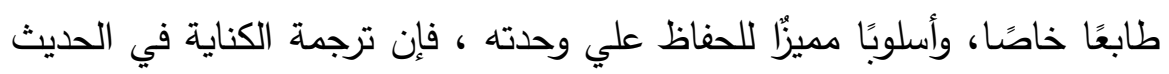

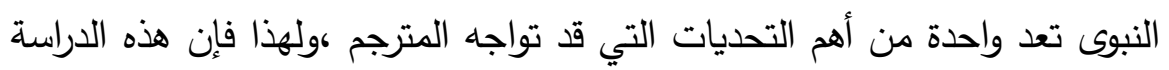

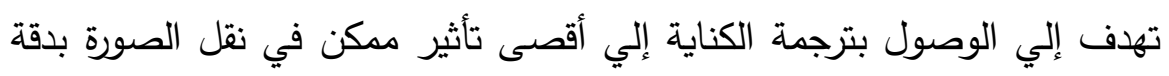

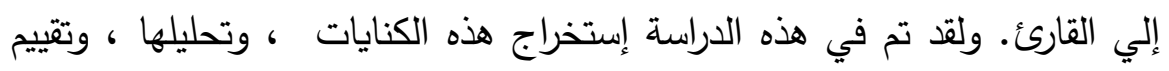

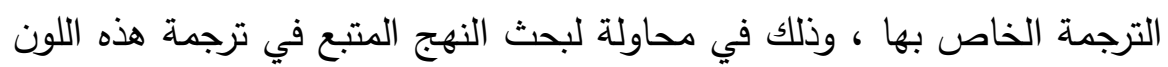

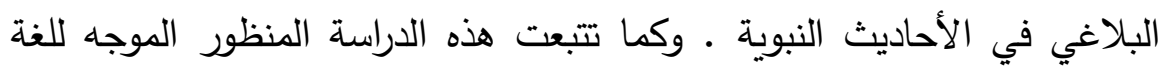
المصدر (Source-Oriented Translation) في الترجمة من أجل الحفاظ لتادئ

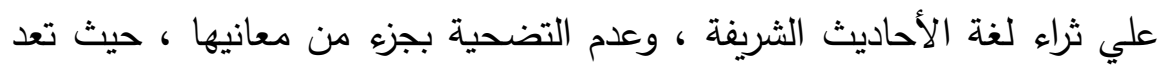

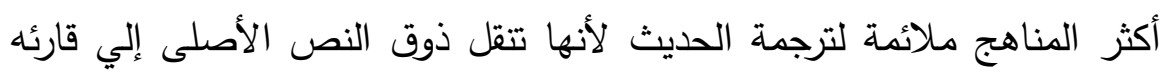
وتعزز قيمه.

الكلمات المفتاحية:

الكناية عن موصوف- الأحاديث النبوية- دراسات الترجمة- المنظور الموجه

للغة المصدر - صحيح البخاري. 
TRANSLATING Kināyah can mawșūf (METONYMY OF A MODIFIED OBJECT) IN SOME PROPHETIC HADITHS

Sahar Muhammed Ahmed Muhammed

مجلة وادي النيل للاراسات والبحوث الإنسانية والاجتماعية والتربوية (مجلة علمية محكمة)

\section{Introduction}

Metonymy plays a decisive role in the interpretation of texts. It is a basic figurative trope, in spoken and written discourse, in which a word is substituted for another that is closely associated or contiguous to it. It can be said that metonymy refers to the use of a term which stands for another. Due to the fact that substitution (a thing is substituted for another that is closely associated) is the central feature of this rhetorical device, it is important to capture its figurative meaning. It can be said that the metonymic meaning can be taken on both planes: the literal and the figurative. In other words, in addition to the figurative meaning that metonymy conveys, it can have the literal meaning. Furthermore, Metonymy has many functions such as making the abstract concrete, adding charm to the meaning and achieving euphemism.

Arabic language is famous for its eloquence and its use of rhetorical language and the Prophetic Hadith (i.e. sayings of the Prophet), is a case in point. . Among the various used rhetorical devices is metonymy of a modified object, the core of this study. Furthermore, Allah has genuinely gifted the Prophet Muhammed (P.B.U.H.) with the most expressive and eloquent words as Allah the Almighty says in His Book:

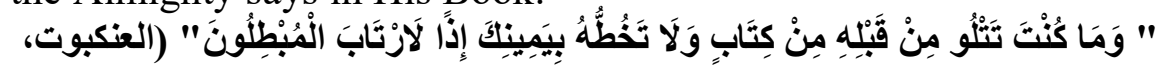

$(\varepsilon \wedge$.

Wamā kunta tatlū min qablihi min kitābin walā takuț̣hu biyamĪnika `dhan llartāba almubțilūn (Al-cankabūt: 48).

"Neither did you (O Muhammed) read any book before it (this Qur'an), nor did you write any book (whatsoever) with your right hand. In that case, indeed, the followers of falsehood might have doubted. "(Khan\& Hilali) (Qur'an 29: 48).

Thus, it is interesting to explore metonymy, mainly when it is discussed under the wave of a religious text and is translated to another language. Moreover, translating metonymy is a focal problem which includes a risky misinterpretation. 
مجلة وادي النيل للاراسات والبحوث الإنسانية والاجتماعية والتربوية (مجلة علمية محكمة)

(ISSN : 2536 - 9555)

\section{Scope of the Study}

It is worth noting here that there are various types of metonymies, such as التلويح al-talūih (waving), الرمز ramz (symbol), الإيماءal-`imāo (gesture) or الإشارةal-`ishārah (sign), and many others. According to Al-Sakkaki's classification of metonymy in his مفتاح العلوم Miftah al- cUlüm (key of sciences) (1937), there are three main types 1) كناية عن صفاحم Kināyah can șifah (Metonymy of an Attribute), 2) كناية عن موصوف Kināyah can كناية عن نسبة (Metonymy of a Modified Object) and 3) Kināyah can nisbah (Metonymy of an affinity). This classification is related to the nature of $a l-m a k n \bar{I}{ }^{c} a n h u$ (the meaning as intended by the speaker) (as in Al-Mahdi's words, 2009, p.13). However, the corpus of this study focuses on one of these types, Kināyah ${ }^{c}$ an mawșūf (metonymy of a modified object), in SaḥI its translation by Khan (1997). These selected metonymic expressions discuss different topics, such as preferring Al-akharah, Islam's concern for animals, loving to meet Allah and the signs of the Hour.

\section{Theoretical Framework}

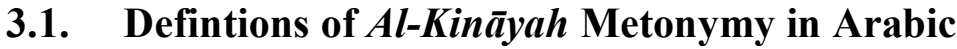

On closer inspection of the various definitions on metonymy, despite the different viewpoints that Arab scholars adopt, most Arab linguists and Rhetoricians agree on the fact that substitution or "stand-for" relationship between related items is the central feature of this trope. To put it differently, metonymy is a basic figurative trope in which a word is substituted for another that is closely associated or contiguous to it. It can be said that metonymy refers to the use of a term which stands for another.

In his seminal book مفتاح العلوم muftāhu al-culümi (Key of Sciences), Al-Sakkaki (1937) discusses metonymy in details and provides the following definition:

$$
\text { ترك التصريح بذكر الثيء إلي ذكر ما بلزمه، لينتقل من المذكور الى المنروك. }
$$

To leave pronouncement of a term and resort to mentioning what that term entails to transfer the interpretation from the mentioned item to the left item (Al-Sharafi's translation, 2000, p.36). 
TRANSLATING Kināyah can mawșū f (METONYMY OF A MODIFIED OBJECT) IN SOME PROPHETIC HADITHS

Sahar Muhammed Ahmed Muhammed

مجلة وادي النيل للاراسات والبحوث الإنسانية والاجتماعية والتربوية (مجلة علمية محكمة)

In a similar vein, in his discussion of metonymy, instead of defining metonymy, Ibn Abi al-Asbah (595-654 A.H. / 1198-1256 A.D.) just identifies one of the functions of metonymy. Ibn Abi alAsbah (1963, p. 143) defines Kināyah as:

$$
\text { أن يعبر المتكلم عن المعنى القبيح باللفظ الحسن، وعن الفاحش بالطاهر. }
$$

Kināyah occurs when the speaker expresses an unpleasant meaning by a pleasant word and an obscene meaning by a pure word (my translation).

In the same line of thought, towards an appropriate definition of metonymy, Al-Qazwinii (1983) defines metonymy as is in the following telling words:

لفظ أريد به لازم معناه مع جواز إر ادته معه. The expression by which one aims at that which implies its meaning, with the possibility of aiming at this at the same time. (Larcher's translation, 2013, p.196)

Still, another recent contribution to metonymy is the one that set out by Tabana (1988). In his well-known treatise معجم البلاغة العربيةMúcjamu Al-Balāghati Al-cArabiyati (Lexicon of Arabic Rhetoric), Tabana (1988) refers to the most famous five definitions of metonymy. He mentions that metonymy is regarded as:

(p. 592-3)

Metonymy is to refrain from naming something directly, opting for using a word that has a description of one of its qualities or features (Muhammed's translation, 2017, p.28).

To sum up, the metonymic meaning can be taken on both planes: the literal and the figurative. In other words, in addition to the figurative meaning that metonymy conveys, it can have the literal meaning.

\subsection{Types of Kināyah Metonymy in the Arabic Language}

Most Arab rhetoricians (Al-Sakkaki, Ibn Al-Athir, Ibn AlSarraj, Al-Qazwinii, Al-Subbki, Al-Teftazi, Al-Maraghi and others) express the view that there are three main types of metonymy. This classification is based on the nature of al-maknI ${ }^{c} a n h u$ (the metonymic meaning as intended by the speaker) as Al- 
Mahdi (2009, p.13) calls it. The three main types are Kināyah ${ }^{c} a n$ sifah (Metonymy of an Attribute), Kināyah can mawșüf (Metonymy of a Modified Object) and Kināyah ${ }^{c}$ an nisbah (Metonymy of an affinity).

\subsection{1. كناية عن صفة Kināyah 'an ṣifah Metonymy of an Attribute}

It is a metonymy in which the modified object and the affinity are mentioned while the modifier is ellipted (Bunnduq, 1996, p.68). It is a metonymy whose meaning represents one item's quality as generosity or speed. Here is an illustrating Quranic example by Faraj (2002, p. 129):

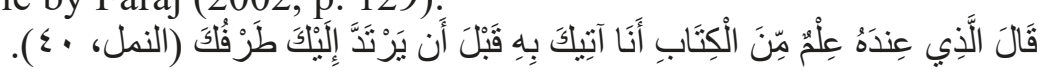
One with whom was knowledge of the Scripture said: "I will bring it to you within the twinkling of an eye!" (Khan\& Hilali) (Qur'an 27: 40).

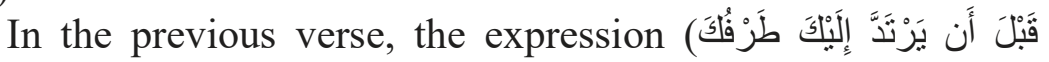
qabla 'an yartadda silayka tarfuk - within the twinkling of an eye) is a metonymy for the attribute (سر عة فائقة - surcatun fã siqatun - super fast speed) (Ibid, p.129).

\subsection{2. كناية عن موصوف Kināyah can Mawșūf Metonymy of a Modified Object}

It is a metonymy in which the attribute and the affinity are mentioned while the modified object is omitted (Bunnduq, 1996, p.69). To make the ideas clear, then consider the following Quranic example by Bunnduq (1996):

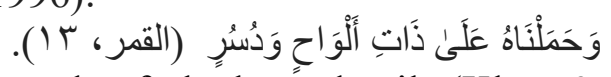

And We carried him on a (ship) made of planks and nails (Khan \& Hilali) (Qur'an 54: 13).

In this verse, Bunnduq (1996) points out that the expression ( ألْوَاح

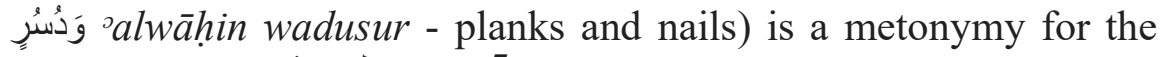
modified noun (السفينة al-safInah - ship). In this Quranic verse, the modified noun (ship) is ellipted but the modifier, planks and nails, is mentioned to denote the ship (p.69).

In a similar vein, Farid (1998) provide excellent examples of this type of metonymy from the Holy Qur'an:

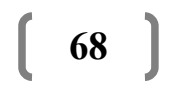


TRANSLATING Kināyah can mawșū f (METONYMY OF A MODIFIED OBJECT) IN SOME PROPHETIC HADITHS

Sahar Muhammed Ahmed Muhammed

مجلة وادي النيل للاراسات والبحوث الإنسانية والاجتماعية والتربوية (مجلة علمية محكمة)

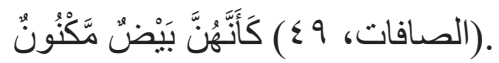

(Delicate and pure) as if they were (hidden) eggs (well) preserved (Khan\& Hilali) (Qur'an 37: 49).

In this verse, the metonymic expression (بَيْضُ baydun - eggs) refers to the modified noun (نساء أهل الجنة nis $\bar{a}^{\circ} u{ }^{\circ}$ ahli al-jannati - women of Paradise) (Farid, 1998, p.50). That is to say, women of the people of the Heaven look like eggs in purity, white colour and softness (Farid, 1998, p. 50).

\subsection{3. كناية عن نسبة Kināyah can Nisbah Metonymy of an Affinity}

It is a metonymy in which both the attribute and the modified object are mentioned However, the required element, the affinity word, is ellipted (Abdul-Raouf, 2006, P. 237). To illustrate the afore-mentioned type, consider the following Quranic verse presented by Farid (1998, p. 36):

$$
\text { وَلَِِنْ خَافَ مَقَامَ رَبِّهِ جَنَّنَانِ(الرحمن، }
$$

But for him who [the true believer of Islamic Monotheism who performs all the duties ordained by Allah and His Messenger Muhammed, and keeps away (abstain) from all kinds of sin and evil deeds prohibited in Islam and] fears the standing before his Lord, there will be two Gardens (i.e. in Paradise) (Khan\& Hilali) (Qur'an 55: 48).

In this metonymy, the modifier (الخوف al-khawf-one's fears from standing before Allah on the Day of Resurrection) and the modified object (Allah) are mentioned. However, the characteristic required attribute, which is the greatness and power of Allah the Almighty, who knows what is apparent and what is hidden, is ellipted. Consequently, one keeps away from all kind of sins and bad behaviour prohibited in Islam (Ibid, P. 36).

\subsection{The Basis of Kināyah Metonymy}

According to Farid (1998), Kināyah is based on الإنتقال من إلي al-`intiqālu mina allāzimi silā al-malzūm a passage from النازم alläzim the consequent to الملزوم طلإم al-malzüm the antecedent, e.g. The passage from thîlu al-nijādi the length of sword 


\section{مجلة وادي النيل للار اسات و البحوث الإنسانية والاجتماعية والتربوية (مجلة علمية محكمة)}

(ISSN : 2536 - 9555)

to كثرة الرماد tūulu al-qamāti the man's height and from kathrat al-ramādi many ashes to الكرم al-karam generosity (p. 41).

\subsection{Metonymy and Translation}

Zheng (2014) identifies that there is a direct correlation between comprehension of metonymy and its translation. That is to say, undersranding the nature of metonymy properly makes the process of its translation easier (p. 33). What is more, Brdar and Brdar Szabo (2014) shed light on one of the fundamental reasons for not rendering metonymy in the SL by means of another metonymy in the TL. They state that if metonymy is a culturalspecific one, then it is hard to translate it by means of metonymy (p. 235).

\subsection{Religion, Culture and Translation}

Prior to the exploration of translating metonymy, one should have a glance at the relation between culture and religion. It is generally true but it should keep in mind that rendering religious texts from one language to another cannot be discussed apart from culture. Abbasi, Salenzadeh, Janfaza, Assemi and Dahjhan (2012) refer to the strong relation between religion and cultutral language (p. 85). Along these lines, it must be borne in mind that translating cultural factors and religious texts cause the most severe challenges in translation. Due to cultural and religious differences, there are some limitations in translating them from the ST into the TT.

\subsection{Source-Orientedness and Target-Orientedness}

Toury (1980) adopts a target-oriented translation in which a translator is in charge of transferring unusual expressions and culture of the source text to some familiar ones for the target readers. On the contrary, source-orientedness is a translation approach whose target is to convey aspects and cultural concepts of the SL into the TL. That is to say, the TL reader moves closer to the SL cultural values and aspects; in turn, exchanging cultures and concepts may take place. As a result, the translated text may have unfamiliar terms of the SL. Toury (1980) disagrees very much with

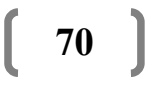


TRANSLATING Kināyah can mawșū f (METONYMY OF A MODIFIED OBJECT) IN SOME PROPHETIC HADITHS

Sahar Muhammed Ahmed Muhammed

مجلة وادي النيل للاراسات والبحوث الإسانية والاجتماعية و التربوية (مجلة علمية محكمة)

source-oriented theories for focusing only on the linguistic and theoretical aspects of the SL. The reason is that he regards translation as facts of the culture that hosts it and invites translators to submit to the culture and text of target language.

\section{Research Questions}

The present study attempts to answer the following research questions:

1. Which translation strategies of Toury's (1995) model have been applied in the English translation of the selected metonymic expressions in the 40 Hadiths at hand by M. M. Khan (1997)?

2. Based on the frequency of use of each strategy in the translated text at hand, which translation strategy can be regarded as the best and most effective translation strategy in conveying culture-specific items in religious texts such as the Prophetic Hadiths?

\section{Method}

\subsection{Procedures}

In order to get a comprehensive understanding of Hadiths at hand, it was essential to read the original Hadith in Arabic, followed by its translation in Khan's (1997) version. Then, metonymies of attributes are extracted manually and listed followed by their translations in Khan's version. The metonymic words/phrases in the SL and its equivalent translation in the TL were underlined and highlighted by using a bold font to enable readers to pick up main quotes easily. An analysis of each Hadith is then provided, based mainly on Ibn Hajar's (n.d.) commentary, Fath al-BārI (Gift of the Maker), which is considered the most reliable commentary on SaḥIh Al-BukhārI , Al-Kirmany's (1981) Al-Kawākibu Al-darārI fī sharḥi Șaḥ̣̂h Al-BukhārI (Al-Darari Planets in Explaining Sahih Al-Bukhari) and Al-Ainii's (2001)

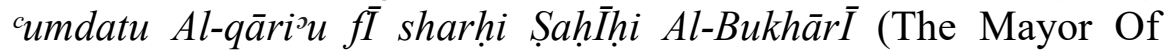

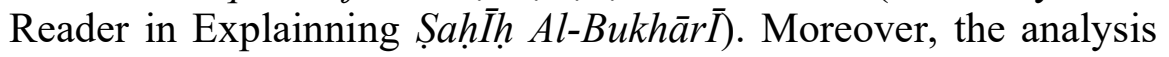


مجلة وادي النيل للاراسات والبحوث الإسانية والاجتماعية والتربوية (مجلة علمية محكمة)

(ISSN : 2536 - 9555)

depends on monolingual Arabic dictionaries such as Ibn Manzur's (n.d.) Lissān al- ${ }^{c}$ Arab (The Arab Tongue) and other dictionaries such as Al-Mucjam al-Wasit. The translation equivalents of metonymies of modified objects are then analyzed and assessed in order to identify the extent to which they are successfully or otherwise translated into English. If the translator fails to transfer these figures effectively and correctly, a suggested translation is provided.

\subsection{Tools}

In this study, a questionnaire is used to avoid subjectivity in the final evaluation of the metonymic expressions.

\section{Subjects}

This questionnaire was administrated to three British male Muslims. Two of them were Egyptians who were born and lived in England and were professional bilingual translators. The other one was Libyan teacher of the English language with M.A. degree. All of them had a long experience in the field. Their ages were between 45 and 55 years.

\section{Materials}

All the respondents were asked to read the metonymic part in Arabic and its translation in English in order to point out whether the translator was able to transfer the Arabic metonymy embedded in each Hadith effectively and correctly or not (see appendix c). They also were asked to interpret this metonymic part in their own words or to suggest another translation if they disagreed with Khan's translation. This questionnaire included the Prophetic Hadith in Arabic and its translation by Khan (1997) respectively, followed by these two questions:

1. Did the translator succeed adequately in rendering the Arabic metonymy embedded in this Hadith?

Yes

No 
TRANSLATING Kināyah can mawșū f (METONYMY OF A MODIFIED OBJECT) IN SOME PROPHETIC HADITHS

Sahar Muhammed Ahmed Muhammed

مجلة وادي النيل للار اسات والبحوث الإنسانية والاجتماعية والتربوية (مجلة علمية محكمة)

2. If you answer with "yes" please interpret this part, using your own words. If you answer with "no", please suggest another translation.

\begin{abstract}
ANALYSIS
The Signs of the Hour

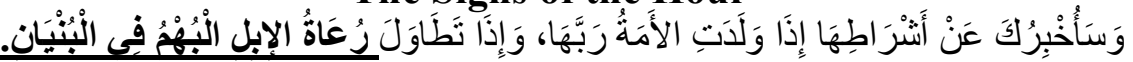
E.g. 1 The Prophet (P.B.U.H.) said, "I will inform you about its portents:

1. When a slave (lady) gives birth to her master. 2. When the shepherds of black camels start boasting and competing with others in the construction of higher buildings. (Book of Belief, Hadith Number 50)
\end{abstract}

\title{
Analysis and Context of Situation
}

The above-mentioned Hadith speaks about the case of the Prophet Muhammed (P.B.U.H.) telling people about two signs that will precede Doomsday. Al-Kirmany (1981, vol. 1) admits that

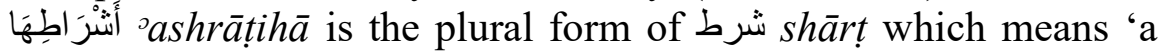
sign' (p. 197).

In this Hadith, the first sign is وَلَدَتِ الأَََنُُ رَبَّهَها waladati al'āmatu rabbahā 'when a slave lady will give birth to her master'. In Arabic, the word رَبَّهَ rabbahā means 'her master/ owner' (AlKirmany, 1981, vol. 1, p. 198). Furthermore, Al-Ainii (2001, vol. 1) identifies that the Prophet (P.B.U.H.) uses $i d h \bar{a}$ as an affirmation tool in order to assert that this sign will happen in the future (p. 446). Al-Ainii (2001, vol. 1, pp. 449- 50) further adds that interpreters of Hadith mention four possible interpretations of the meaning of this sign:

1. The slave-girl will give birth to her kids, who will become free as their dads. In so doing, her kids will be her masters.

2. Others identify that people degenerate and will sell slave females from whom they have their kids. In what 


\section{مجلة وادي النيل للاراسات و البحوث الإنسانية والاجتماعية والتربوية (مجلة علمية محكمة)}

(ISSN : 2536 - 9555)

follows, those slave females' children may buy their mums as slaves without their knowledge.

3. The children of slave females will free their mothers after the death of their fathers. Consequently, they will become their mum's masters.

4. At the end of the world, disobedience to parents will be widespread and children will not honour their parents and will become disrespectful and so bad mannered towards their parents. Accordingly, they will mistreat their mothers, like slaves. This view is the one favoured by Ibn Hajar (vol. 1, p. 123).

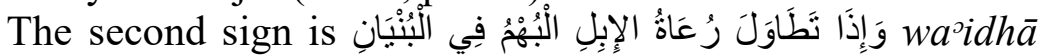
tațāwala ru'ātu al-จibili al-buhmu $f \bar{I}$ al-bunyān 'When the shepherds of black camels start boasting and competing with others in the construction of higher buildings'. Al-Ainii (2001, vol. 1) mentions that نَََّ tatâَwal means 'vie, compete and boast'.

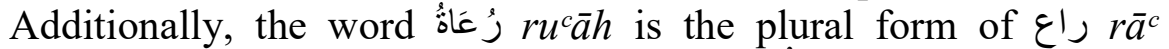
which means 'a shepherd' and the word الُُْْْ8 al-buhm denotes 'a baby lamb' (p. 444). Then, Al-Ainii (2001, vo. 1) adds that this sign states that Bedouin people, who were primarily shepherds and destitute goat-herb, will compete amongst each other in the construction of tall buildings for the sake of being more prestigious. What is more, he also asserts that shepherds of black camels denote Arabs who were known for grazing sheep and camels. It can be said that this is a sign of spreading Islam at the end of the world (p. 450). The prophecy mentioned above has been fulfilled in the Arabian Peninsula where there are the tallest sky scrapers in the world. However, building and competing in constructing magnificent and huge buildings are against Islamic principles if it does not address practical needs; i.e. if there is no need for that.

To sum up, the Prophet (P.B.U.H.) confirms that no one knows the Day of Judgement and this does not underestimate the Prophet's knowledge. However, he could tell people about the portents and signs of the Day of Judgement. 
TRANSLATING Kināyah can mawșū f (METONYMY OF A MODIFIED OBJECT) IN SOME PROPHETIC HADITHS

Sahar Muhammed Ahmed Muhammed

مجلة وادي النيل للاراسات والبحوث الإسانية والاجتماعية والتربوية (مجلة علمية محكمة)

\section{Explaining Metonymy}

Al-Khataby, as cited in Ibn Manzur (n.d.), argues that

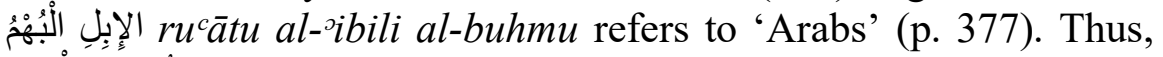

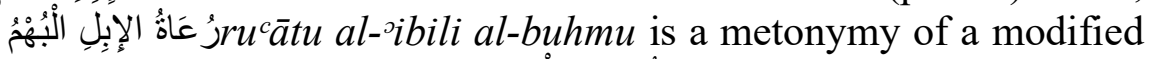

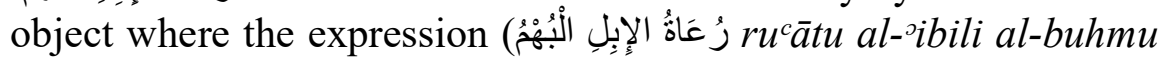
-shepherds of black camels) refers to the modified noun (العرب) alcarab-Arabs who were the inhabitants of desert) (Hijazii, 1986, p. 52).

\section{Assessment}

In this translation, the metonymic use of language is relayed and the translated text is rendered in the TL as rich as it is in the Arabic composition. Khan (1997) adopts the strategy of sourceorientedness in order to introduce an adequate translation. However, he uses the adjective (black) in order to reproduce this image which is not part of the Hadith at hand. This adjective should be included between parentheses so as to alert the reader that is not part of the original text.

\section{Suggested Translation}

... the shepherds of (black) camels.

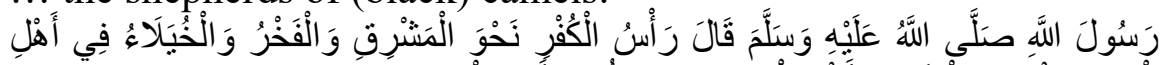

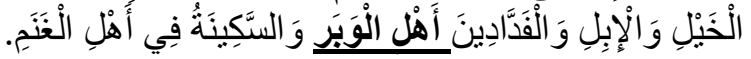

E.g. 2 Allah's Messenger (P.B.U.H.) said, "The main source of disbelief is in the east. Pride and arrogance are characteristics of the owners of horses and camels, and those Bedouins who are busy with their camels and pay no attention to Religion; while modesty and gentleness are the characteristics of the owners of sheep"( Book of Beginning of Creation, Hadith Number 3301).

\section{Analysis and Context of Situation}

In the aforementioned Hadith, the Prophet (P.B.U.H.) speaks about the pride and arrogance of the owners of camels. This is because having camels and horses give prestige to their owners at that time. As a result, they were busy with camels; in turn, they 
مجلة وادي النيل للاراسات والبحوث الإنسانية والاجتماعية والتربوية (مجلة علمية محكمة)

(ISSN : 2536 - 9555)

paid no attention to religion. On the contrary, the owners of sheep were characterized by gentleness and humble.

Ibn Hajar (vol. 6) identifies that رَأَسُ الْكُفْرِ نَحْوَ الْمَشْْْرِي rassu alkufri nahwa al-mashriqi refers to the strong disbelief of Magus (Magians) because Medina was bordered by the Persian Empire (Persian/ Iranian people) and their Arab followers to the East. Those Magus were so pride and arrogant until the Prophet (P.B.U.H.) beat them. He also adds that li al-fakhru denotes

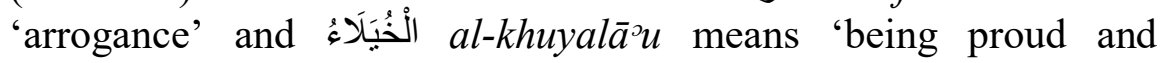
disrespecting others' (p. 352). Furthermore, Al-Khattabi, cited in Al-Ainii (2001, vol. 15), interprets the word الْفَدَاِِينَ al-faddadIIna to refer to either of the following meanings. He admits that the Arabic

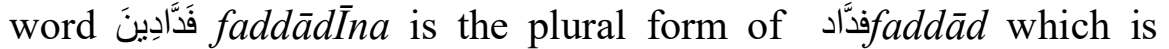
derived from the root $f a d \bar{I} d$, meaning 'loud pitched voice' that is one of the characteristics of their high standing in society. He adds that it can be the plural form of ف faddān, denoting 'a war machine' (p. 262). Additionally, Ibn Hajar (vol. 6) states that Arabs used to refer to 'Bedouins and inhabitants of the desert' as أَهْلِ الَْوَبَ sahlu al-wabari. The expression أَهْلِ الََْبَرِ ohlu al-wabari 'people of mohair' means that those people are the main source of 'wool and mohair' of sheep (p. 352). In Arabic, the word السَّكِيَّة al-ssakInatu means 'humility, peace, dignity and gentleness' (Ibid, p. 352).

\section{Explaining Metonymy}

The expression أَهْلِ الْوَبَ oahlu al-wabari is a metonymy for the modified noun 'the inhabitants of desert/ Bedouins' (Al-Ainii, 2001, vol. 15, p. 263).

\section{Assessment}

The metonymy here is lost and its literal meaning is used. The original text uses a metonymy in which the Prophet refers indirectly to the inhabitants of the desert (Bedouins) and uses one of their characteristics 'people of mohair'. In other words, the translator fails to reproduce this image. He renders the translation of this part using the strategy of target-orientedness as he sacrifices 
TRANSLATING Kināyah can mawșū f (METONYMY OF A MODIFIED OBJECT) IN SOME PROPHETIC HADITHS

Sahar Muhammed Ahmed Muhammed

مجلة وادي النيل للار اسات والبحوث الإنسانية والاجتماعية والتربوية (مجلة علمية محكمة)

the metonymic power used in the SL for the sake of elegance and intelligibility in the TL.

\section{Suggested Translation}

... people of mohair (Bedouins who are busy with their camels)...

\section{Preferring Al-Akhrah}

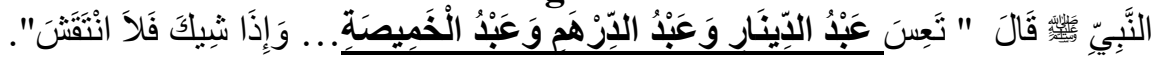

E.g. 3 The Prophet said, "Let the slave of Dinar and Dirham and

Khamisa perish .... and if he is pierced with a thorn, let him not find anyone to take it out for him" (Fighting for the Cause of Allah (Jihad), Hadith Number 2887).

\section{Analysis and Context of Situation}

In the previous mentioned Hadith, Ibn Al-Tiin, as cited in Al-Ainii (2001, vol. 14), explains the meaning of التَعِسَ al-tacisu as al-kab, denoting 'being hindered and fell on one's face' (p. 24). Additionally, Ibn Al-Anbaarii, cited in Al-Ainii on the same page, admits that التَعَِسَ'tacisu means 'evil'. In the same vein, Ibn

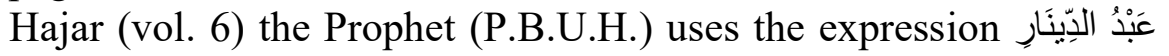
${ }^{c} a b d u$ al-dināri to refer figuratively to those people who prefer aldunyā (worldly matters) and worship its materialistic pleasures (p. 82). Furthermore, Al-Ainii (2001, vol. 14) points out that الْخَمِيصَنَة al-kham $\overline{I s}_{\text {ati }}$ is a type of black square outer-clothing, a cloak bordered with silk (p. 241). Moreover, Ibn Bital, as cited in AlAinii (2001, vol. 14), admits that إِنْ أُعْطِيَ in ' ${ }^{\circ} u^{c}$ tiyya refers to those people who are satisfied if they are given the enjoyments of the world; otherwise they are dissatisfied. This is why the Prophet (P.B.U.H.) uses the word عَبْ c cabdu ' a slave' to describe those people whose main concern is all about money; in turn, being cursed for their lusts. The expression وَ إِذَا شِيَكَ waridha shI $k a$ denotes 'being pricked with a thorn' and انتقََ الرجل sintafasha al-rajulu means that 'a man takes the throne out from his feet' (p. 241).

In this Hadith, the Prophet (P.B.U.H.) describes those people who care only about money and expensive clothes. He has cursed people who are slaves of their lusts instead of Allah. A true 
مجلة وادي النيل للاراسات والبحوث الإنسانية والاجتماعية والتربوية (مجلة علمية محكمة)

(ISSN : 2536 - 9555)

Muslim should prefer al-akhira. This is because it is eternal and the enjoyments of the world are temporary.

\section{Explaining Metonymy}

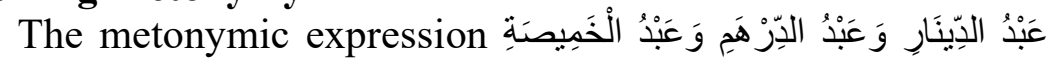
cabdu al-dināri wa cabdu al-ddirhami wa cabdu al-khamIșati refers to the modified noun 'worshippers of the world's enjoyments' (Hijazii, 1986, p. 101).

\section{Assessment}

The translation of this metonymy is successfully produced in the English version. Although the cultural element is retained, its translation is still vague and unclear for the TL readers. This is why the researcher has suggested providing the direct meaning of these cultural elements in parentheses to avoid any vagueness and to ascertain the reader's comprehension of the intended meaning of Dinar and Dirham, types of currency, and khamisa, a fine and expensive cloth. Additionally, the researcher has added 'with a thorn' into brackets in order to alert the reader that it is not a part of the original text. Moreover, she has suggested using 'not taking it out (for him)' so as to be close to the original in lexis and the finest style of metonymy.

\section{Suggested Translation}

... let the slave of Dinar and Dirham (types of currency) and khamisa (a black cloak bordered with silk) perish... and if he is pierced (with a thorn), not taking it out (for him).

\section{Islam's Concern for Animals}

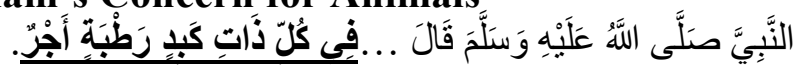

E.g. 4 The Prophet (P.B.U.H.) said... there is a reward for serving any animate (living being)" (Book of Oppressions, Hadith Number 2466).

\section{Analysis and Context of Situation}

In the above-mentioned Hadith, the Prophet (P.B.U.H.) teaches Muslims how to treat animals kindly and clarifies the 
TRANSLATING Kināyah can mawșū f (METONYMY OF A MODIFIED OBJECT) IN SOME PROPHETIC HADITHS

Sahar Muhammed Ahmed Muhammed

مجلة وادي النيل للاراسات والبحوث الإنسانية والاجتماعية و التربوية (مجلة علمية محكمة)

reward for feeding animals in Islam. In this Hadith, the Prophet (P.B.U.H.) told His companions about the man who was thirty, and then he found a well. After quenching his thirst, he saw a dog that suffered from excessive thirst. Therefore, he went down the well again, filled his shoes with water, climbed up and watered the dog. Consequently, Allah the Almighty accepted his great deed and forgave him for all his previous evil deeds. Allah's forgiveness reflects Islam's concern for animals. What is more, the Prophet (P.B.U.H.) advises people to be merciful towards every living creature. In this respect, Al-Ainii (2001, vol. 12) points out that the

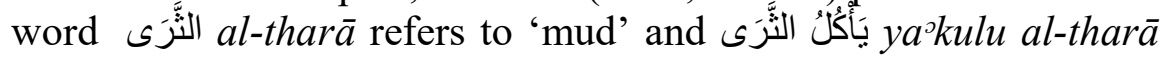
means 'licking mud/ ground' and the word خُفْ $k$ khuffu means 'shoe' (p. 290). Moreover, he explains that the verb يَلْهَ yalhathu denotes 'panting and lolling its tongue' (Ibid, p. 290). Moreover, Ibn Hajar (vol. 5) remarks that فَغَفَرَ لَهُ means that 'Allah accepts the good deed of this kind man; in turn, Allah forgives him' (p. 42). Additionally, Al-Dawudy, as cited in Ibn Hajar on the same page,

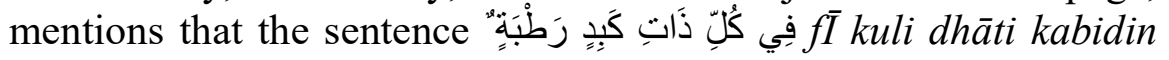
rațatin 'ajrun refers to 'the liver of every-living creature'.

\section{Explaining Metonymy}

Ibn Hajar (vol. 5) points out that رَطْبَathatin means 'moisture needed for life'. In other words, it is a metonymy because 'moisture is lazim (an entailment) of life (p. 42). Thus, it

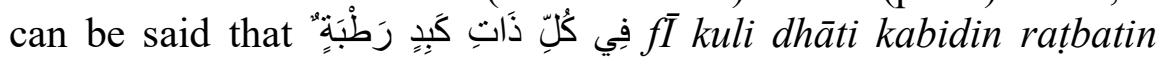
`ajrun is a metonymy for the modified noun 'every living-being'. The Prophet (P.B.U.H.) uses the word 'liver' to gain sympathy from people towards living creatures (Hijazii, 1986, p. 138).

\section{Assessment}

The metonymy mentioned above is obliterated through using the direct meaning "for serving any animate". It might be the translator avoids the metonymic expression in order to avoid any misunderstanding. The translator seems to submit himself to the linguistic norms and the culture of the TL, target-orientedness. 


\section{مجلة وادي النيل للاراسات والبحوث الإنسانية والاجتماعية والتربوية (مجلة علمية محكمة)}

(ISSN : 2536 - 9555)

However, he should use the metonymy used in the Arabic composition, followed by the direct meaning between parentheses.

\section{Suggested Translation}

... there is a reward for every animate with moist liver (for serving every living-being).

Manumission of Slaves in Islamic Laws

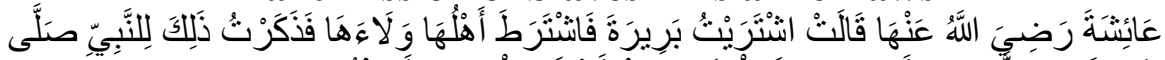

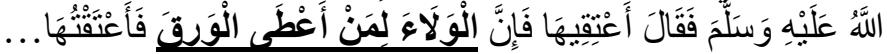

E.g. 5 Narrated 'Aisha: I bought Buraira but her masters put the condition that her Wala' would be for them. I told the Prophet (P.B.U.H.) about it. He said (to me), "Manumit her as her Wala' will be for the one who pays the price". So, I manumitted her... (Book of Manumission of Slaves, Hadith Number 2536).

\section{Analysis and Context of Situation}

Ibn Manzur (n.d.) defines the word الْوَرِقَ al-wariqa as الدراهم and al-darāhim dirhams (a sort of coins) and silver (p. 4816). Additionally, Al-Khatabi, cited in Ibn Hajar (vol. 5), identifies that wala $^{\circ}$ (kinship/affinity), resulted from emancipating slaves, is as establishing relations by blood. As a result of this sort of relationship, there is a right of inheritance between a freed slaves and the person who emancipated him/ her (p. 167).

This Hadith deals with one of the basics of Islam, wala ${ }^{\top} a \mathrm{Al}$ 'tiq (kinship by emancipation). The Mother of Believer, 'Aisha, brought a slave girl called Buraira whose master did not mind to sell her on the condition that her wala ${ }^{\supset}$ (loyalty and inheritance) after her death should be for him. However, the Prophet (P.B.U.H.) said that Buraira's walāo was for the one who paid the price. After that, the Prophet (P.B.U.H.) gave her a choice to stay with her husband or leave him and she chose herself, refusing to go back to her husband (Al-Ainii, 2001, vol. 13, pp. 137-38).

\section{Explaining Metonymy}

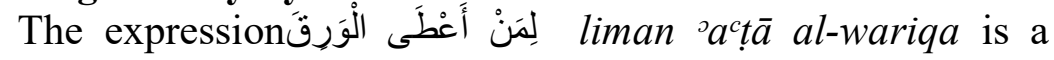
metonymy for the modified noun 'a person who pays the silver and 
TRANSLATING Kināyah can mawșū f (METONYMY OF A MODIFIED OBJECT) IN SOME PROPHETIC HADITHS

Sahar Muhammed Ahmed Muhammed

مجلة وادي النيل للاراسات والبحوث الإنسانية والاجتماعية والتربوية (مجلة علمية محكمة)

dirhams to emancipate a slave'. After that, this person becomes the master of the emancipated slave and has the right of his/ her loyalty and inheritance. The Prophet's examples, i.e. silver and dirhams, were chosen from the environment around people in this era in order to be related to their minds and perceptions (Hijazii, 1986, p. 140).

\section{Assessment}

Khan (1997) fails to render the metonymy and the cultural input here. He drops the eloquent use of الَْرِقِقَ al-wariqa and does not identify the meaning of al-wal $\bar{a}^{\circ}$ in translation. It can be said that he follows the linguistic and cultural norms of the TL, using the strategy of target-oriented, overlooking the mentioned metonymy.

\section{Suggested Translation}

... her wala ${ }^{\supset}$ (loyalty and inheritance after death) is for the one who gives the silver (i.e. pays the price for freeing/ manumitting a slave).

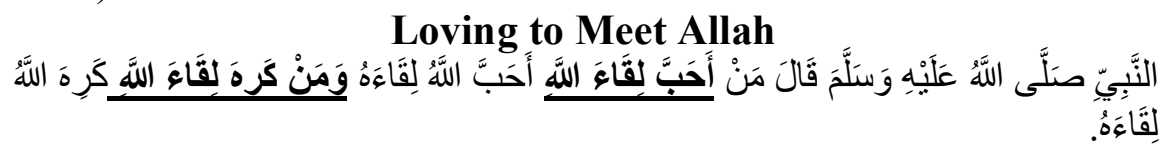

E.g. 6 The Prophet (P.B.U.H.) said, "Who-ever loves to meet $\underline{\text { Allah, }}$ Allah (too) loves to meet him and who-ever hates to meet Allah, Allah (too) hates to meet him"(Book of to Make the Heart Tender (Al-Riqaq), Hadith Number 6507).

\section{Analysis and Context of Situation}

Al-Nawaawi, cited in Al-Kirmany (1981, vol. 23), clarifies what is meant by "loving or hating to meet Allah". He admits that loving or hating to meet Allah is related to the feeling that a person has when the time of his/ her death approaches. This is because people are given glimpses of their destiny after death. To put it differently, on the one hand, a believer receives glad tidings of Allah's blessings and pleasure upon him/ her and of his/ her place 


\section{مجلة وادي النيل للاراسات والبحوث الإنسانية والاجتماعية والتربوية (مجلة علمية محكمة)}

(ISSN : 2536 - 9555)

in Jannah (the paradise). Consequently, s/he is eager to meet Allah and loves His meeting after death. On the other hand, a disbeliever receives the news of Allah's torment, His wrath and the punishment of Jahannum (The Hell-Fire). Because of his shortcomings and disobedience to Allah's commands, s/he hates death; in turn, s/he hates to meet Allah (pp. 25-6). In this respect, there is no contradiction between people's dislike of death, which is normal, and loving to meet Allah.

\section{Explaining Metonymy}

The sentence كَرَه لِقَاءَ اللهّ waman kariha liq $\bar{a}^{\top}$ a Allahi is a metonymy for the modified noun (الموت al-mawt- death) (Hijazii, 1986, p. 146). In line with this orientation, Al-Kirmany (1981, vol. 32, pp. 26) states that لِقَاءَ السَّه liq $\bar{a}^{\supset} a$ Allahi denotes one of the following meanings:

1. Death as it is mentioned in the following Qur'anic verse (29:5):

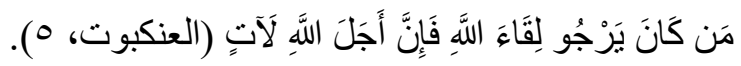

Man kana yarjū liq $\bar{a}^{\supset}$ a Allahi fa ${ }^{\circ}$ inna ${ }^{\circ}$ ajala Allahi la ${ }^{\circ} a t i n$ (Alcankabüt: 5).

Whoever hopes for the Meeting with Allah, then Allah's Term is surely coming (Khan\& Hilali).

2. البعث al-bacth Resurrection of the body as in (Qur'an 6: 31):

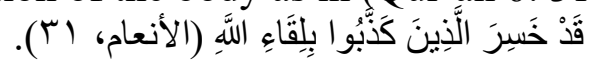

Qad khasira al-ladhĪna kadhdhabū biliq $\bar{a}^{\circ} i$ Allahi (Al- $\left.{ }^{\circ}{ }^{c}{ }^{c} \bar{a} m: 31\right)$. They indeed are losers who denied their Meeting with Allah (Khan\& Hilali).

\section{Seeing Allah.}

\section{Assessment}

Both translations of the two metonymies are successfully reproduced in the English version as plentiful as in the Arabic composition. The translator uses the expression "love to meet Allah- hate to meet Allah", adopting the strategy of sourceorientedness. However, this metonymy should be followed by an 
TRANSLATING Kināyah can mawșū f (METONYMY OF A MODIFIED OBJECT) IN SOME PROPHETIC HADITHS

Sahar Muhammed Ahmed Muhammed

مجلة وادي النيل للاراسات والبحوث الإسانية والاجتماعية والتربوية (مجلة علمية محكمة)

explanatory note between parentheses in order to avoid any misunderstanding.

\section{Suggested Translation}

... whoever loves to meet Allah (at the time of death when being shown glimpses of his approaching destiny)... whoever hates to meet Allah (at the time of death when being shown glimpses of his approaching destiny).

How to be Devout Worshippers

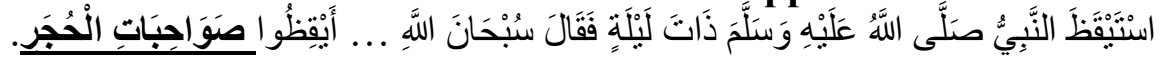
E.g. 7 One night Allah's Messenger (P.B.U.H.) got up and said, "Subhan Allah! ... Go and wake the sleeping lady occupants of these dwellings (his wives) up (for prayers)" (Book of Knowledge, Hadith Number 115).

\section{Analysis and Context of Situation}

In this Hadith, Ibn Hajar (vol. 1) clarifies that سُبْحَانَ اللَّهِ subhāna Allahi denotes the Prophet's state of astonishment because of Allah's mercy and afflictions that have been descended at that night. Besides, the Prophet(P.B.U.H.) uses the word خَزَ ائِنِ khazāin 'treasures' to refer to 'Allah's mercy' as in the Quranic verse (Qur'an r8: 9):

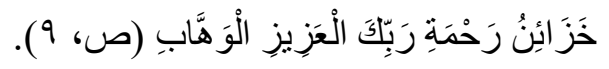

khazāoinu raḥmati rabbika al-cazizi al-wahābi (s: 9).

"Have they the treasures of the Mercy of your Lord, the AllMighty, the Real Bestowed? (Khan\& Hilali)

The Prophet (P.B.U.H.) also uses the word الْفَنَّel al-fitani (afflictions) to refer to 'torments and punishments' (p. 211). By the same token, Al-Ainii (2001, vol. 2) identifies that the passive form

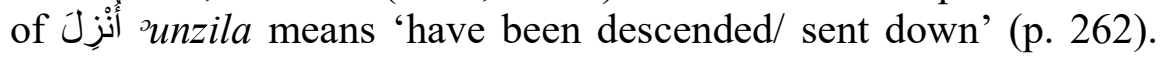
Furthermore, the word șawāhibāti /ṣawāhiba is the plural form of صَّâhibah which denotes 'an owner/ an حُجرة al-hujar is the plural form occupant' and the word الْحَجَرِ hujrati, meaning 'the houses of the Prophet's wives' (Ibid, p. 262). 
مجلة وادي النيل للاراسات والبحوث الإنسانية والاجتماعية والتربوية (مجلة علمية محكمة)

(ISSN : 2536 - 9555)

This Hadith deals with the man's responsibility for teaching and guiding his wife. Al-Munajjid (2014) explains the meaning of this Hadith in the following telling words:

The messenger of Allah, sallaalhahu 'alayhi wa sallam, was astonished at the fact that people were heedless of the extent of rewards and afflictions because this should stimulate them to rejoice (for the reward) and fear the punishment awaiting those who commit the evil. This is why he, sallaalhahu 'alayhi wa sallam, asked that his wives be woken up. This was an indication from him to his wives that they should not be heedless of performing acts of worship, and that they should not simply rely on the fact that they are the wives of the Prophet of Allah, sallaalhahu 'alayhi wa sallam. (Al-Munajjid, 2014, p. 94)

To put it differently, the Prophet (P.B.U.H.) had taught His wives to be devout Muslim women. What is more, Al-Munajjid (2014) adds that "this narration encourages husbands to wake their wives up to pray at night, especially during the times when a celestial event is happening (i.e. like strong winds, hurricanes, tornadoes, eclipse and so on)" (p. 94).

\section{Explaining Metonymy}

Al-Ainii (2001, vol. 2) states that sَawâahibāti al-hujar refers to the Prophet's wives. Consequently, it can be said that the expression صَوَاحِبَاتِ الْحُجَرِ sawāhibāti al-ḥujar is a metonymy for the modified noun 'the mothers of Believers, the Prophet's wives'.

\section{Assessment}

In this Hadith, Khan (1997) succeeds in rendering the mentioned metonymy equally at the same level of the Arabic version, by using "occupants of the dwellings", followed by "his wives' and 'for prayers' in parentheses in order to ascertain that the foreign reader will receive the intended meaning. He uses the norms realized by the SL plus certain modifications, adopting the source-orientedness. 
TRANSLATING Kināyah can mawșū f (METONYMY OF A MODIFIED OBJECT) IN SOME PROPHETIC HADITHS

Sahar Muhammed Ahmed Muhammed

مجلة وادي النيل للاراسات والبحوث الإنسانية والاجتماعية والتربوية (مجلة علمية محكمة)

Chastity of Tongue and Private Parts

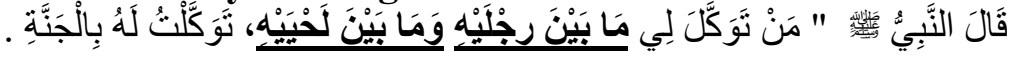

E.g. 8 \& 9 The Prophet said, "Whoever guarantees me (the chastity of) what is between his legs (i.e. his private parts), and what is between his jaws (i.e., his tongue), I guarantee him Paradise." (Limits and Punishments Set by Allah (Hudood), Hadith Number 6807).

\section{Analysis and Context of Situation}

The above Hadith speaks about the reward of guarding the chastity of tongue and private parts. Al-Ainii (2001, vol. 23) identifies that تَوَكَّلَ tawakkala denotes 'guarantee and guard' and the expression 'what is between his two legs' refers to 'one's private parts' (p. 447). Besides, Al-Daarady, cited in Ibn Hajar (vol. 11), states that 'what is between his two jaws bones' refers to 'one's mouth' which is a vital organ and essential for drinking, eating and talking (pp. 309-10). Ibn Hajar (vol. 11) further adds that great afflictions and evils may result from these two organs: tongue and private parts (p. 310). That is to say, if a person minds his words and handles his tongue well, it is a path to paradise. Furthermore, the reward of guarding one's private parts and its chastity is paradise (Al-Ainii, 2001, vol. 23, p. 447).

\section{Explaining Metonymy}

In this Hadith, Hijazii (1986) admits that there are two metonymies of modified objects:

\section{E.g. 8 oَا بَيْنَ رِجْلَيْهِ}

The expression مَا بَيْنَ رِجْلَيْهِ $m a \bar{~}$ بَ bayna rijlayhi 'what is between his legs' is a metonymy for the modified object 'one's private parts' (p. 156).

\section{E.g. 9 mā bayna lahyayhi}

The expression كَا بَيْنَ لَحْيَيْهِ may bayna lahyayhi 'what is between his jaws' is a metonymy for the modified object 'one's mouth' (p. 156). 
مجلة وادي النيل للاراسات والبحوث الإنسانية والاجتماعية والتربوية (مجلة علمية محكمة)

(ISSN : 2536 - 9555)

\section{Assessment}

The translator succeeds in reproducing these both translations in the English version. He utilizes the source-oriented translation in order to transfer the Arabic meaning as much as possible into the English TL, followed by certain modifications to enable the target reader to capture the required meaning.

\section{Story of Ismail's Wives}

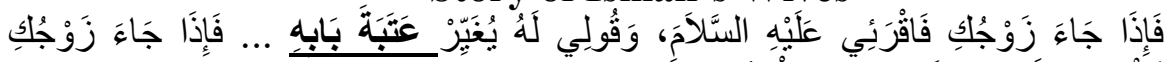

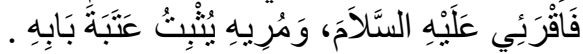

E.g. 10 'When your husband returns, convey my salutation to him and tell him to change the threshold of the gate (of his house).... "When your husband comes, give my regards to him and tell him that he should keep firm the threshold of his gate.'(Book of Prophets, Hadith Number 3364).

\section{Analysis and Context of Situation}

In this Hadith, the Prophet (P.B.U.H.) has narrated the story of Hajar, the Prophet Ibrahim's wife, and her son, Ismail. He has also narrated the events that have followed their residence in Makkah. After a long time, the Prophet Ibrahim decided to go Makkah to see his son, Ismail, but he did not find him at home. In his speech with Ismail's wife, the Prophet Ibrahim asked her about their condition and living. Ismail's wife complained about their misery and poverty but she did not know that he was her husband's father. Then, he left and asked her to convey his greeting to Ismail and to tell him to change the doorstep of his house. After conveying the message of the Prophet Ibrahim, Ismail divorced this wife and married another one. 'Changing the threshold of his gate' was an indirect message from the Prophet Ibrahim to his son to divorce his wife. After a long time, the Prophet Ibrahim came back again to his son, but Ismail had gone to seek livelihood and was not at home. The new wife was grateful and thanked Allah for His gifts despite their hard life. As a result, the Prophet Ibrahim asked her to convey his salvation to Ismail and to tell him to keep firm his doorstep. 
TRANSLATING Kināyah can mawșū f (METONYMY OF A MODIFIED OBJECT) IN SOME PROPHETIC HADITHS

Sahar Muhammed Ahmed Muhammed

مجلة وادي النيل للاراسات والبحوث الإنسانية والاجتماعية والتربوية (مجلة علمية محكمة)

In the previous mentioned Hadith, the principled laid down of how grateful wives should be good for all times. Upon to this point, Abdul-Rahman (2018) states that:

The Hadith relates, Prophet Ibrahim disapproved of Ismail's marriage to an ungrateful woman and later approved of his son's marriage to another woman who was grateful. Both of the women lived in the same condition, which was one of hardship, but the greater hardship was the ingratitude of the ungrateful wife, and Ismail divorced her when Ibrahim recommended a change to the gate. (Abdul-Rahman, 2018, p. 110)

\section{Explaining Metonymy}

The expression بَتَبََبَ catabata bābihi is a metonymy for the modified noun (المرأة al-marah- woman) because there are some commonly shared characteristics between 'one's wife and the doorstep of house'. This is because both of them are responsible for keeping home safely and things inside home (Ibn Hajar, vol. 6, p. 404; Al-Ainii, 2001, vol. 15, p. 356).

\section{Assessment}

The previous translation overtly puts source-orientedness in practice as it is equivalent to the original text. Thus, it can be said that the translator succeeds in reproducing this metonymy, using the linguistic and cultural norms of the TL. However, he should follow this metonymy by certain modifications so as to enable the target reader to capture the required meaning. Additionally, the translator should not put the phrase 'of his house' between parentheses because it is a part of the original text; in turn, it misleads the TL readers.

\section{Suggested Translation}

... change the threshold of the gate of his house (change his wife by divorcing her) ...

Distinguishing the True Dawn from the False Dawn 
(ISSN : 2536 - 9555)

أخذ عدي عقالا أبيض وعقالا أسود، حتى كان بعض الليل نظر، فلم بستيينا... (إن

وسادك إذا لعريض....).

E.g. 11 'Adi took a white rope (or thread) and a black one, and when some part of the night had passed, he looked at them but he could not distinguish one from the other. ..."Then your pillow is too wide ... ( Book of Prophetic Commentary on the Qur'an, Hadith Number 4509).

\section{Analysis and Context of Situation}

The Hadith mentioned above, the Prophet (P.B.U.H.) has told people how to identify the time of fast which depends mainly on distinguishing the white thread of dawn from the black thread of dawn. In another Hadith, the Prophet (P.B.U.H.) has clarified what is meant by 'the white thread' and 'the black thread'. The expressions 'the white thread' and 'black thread' refer to 'the whiteness of the daylight' and 'the blackness of the night'.

Some scholars have assumed that 'Adi, one of the Prophet's companions, did not hear the Prophetic Hadith narrated by Sahl in which the meaning of 'the white and the black threads' was explained clearly. This was why 'Adi did not understand the real meaning of these expressions. As a result, he put two threads, white and black, under his pillow in order to distinguish the streaks of the true dawn. Then, he went to the Prophet (P.B.U.H.) and complained to Him that he could not tell the two threads apart when looking at them. The Prophet (P.B.U.H.) clarified that the white thread denotes 'the day' and the black thread denotes 'the night'.

Ibn Hajar (vol. 4) admits that عقال ciqāl refers to خيط khayt which means threads/ strings (p. 133). Additionally, Ibn Manzur (n.d.) states that gis wis is derived from the root $د$ w 2 w $s d$ which means المِخَدْة al-mikhadah 'a pillow' (p. 4830). Furthermore, Al-Zamakhashary and some scholars, cited in Ibn Hajar (vol. 4), have claimed that the Prophet (P.B.U.H.) has used the expression wisādak carĪ of understanding'. However, many scholars have rejected this claim and its interpretation (p. 133). 
TRANSLATING Kināyah can mawșū f (METONYMY OF A MODIFIED OBJECT) IN SOME PROPHETIC HADITHS

Sahar Muhammed Ahmed Muhammed

مجلة وادي النيل للاراسات والبحوث الإنسانية والاجتماعية والتربوية (مجلة علمية محكمة)

\section{Explaining Metonymy}

Ibn Hajar (vol. 4, p. 133) and Ibn Manzur (n.d., p. 4830) admit that the metonymic expression وسادك عريض wisādak carİ can be interpreted as follows:

1. The expression وسادك عريض wisädak carI for the modified noun "one's much sleep".

2. The expression وسادك عريض wisādak carI for the modified noun "one's long night" if one is allowed to eat and drink till the white thread become distinct from the dark thread when looking at them.

3. The word 'pillow' is used metonymically to refer to the part of the head and neck that one puts on the pillow while sleeping. Consequently, وسادك عريض wisādak carỊ a metonymy for the modified object 'the backside of the neck/ the back of the head', denoting if the pillow covers the white and the black threads (day and night) under it, the backside of head and neck are huge and wide (p. 133).

\section{Assessment}

Although Khan (1997) conveys the metonymic expression into the TL, it is too tricky to non-Arab readers to anticipate the meaning of 'qafã: the backside of head and neck' from this metonymic term as it is ambiguous. Therefore, the researcher has suggested using the metonymy, followed by a parenthetical statement. Khan (1997) here adopts source-oriented translation.

\section{Suggested Translation}

"Then your pillow (backside of your head and neck) is too wide if the white thread (of dawn) and the black thread (of the night) are underneath your pillow!"

The Attachment of some People to the World

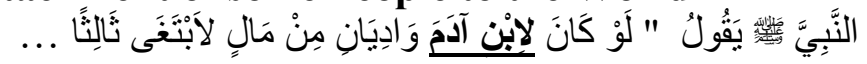

E.g. 12 I heard the Prophet saying, "If the son of Adam (the human being) had two valleys of money, he would wish for a 
مجلة وادي النيل للاراسات والبحوث الإنسانية والاجتماعية والتربوية (مجلة علمية محكمة)

(ISSN : 2536 - 9555)

third ... (To Make the Heart Tender (Al-Riqaq), Hadith Number 6436).

\section{Analysis and Context of Situation}

This Hadith speaks about the nature of some people whose hearts are attached to the world. The Prophet (P.B.U.H.) mentions that humankind had two valleys full of money and riches; he would seek a third one. This is why Al-Taybii, cited in Ibn Hajar (vol. 11), human-being is fond of temporal life and its material and does not feel satisfied with life's pleasures except those whom Allah guides them to the right path (p. 256). In this respect, Al-Anii (2001, vol. 23) says that the word ابَتْنَّى oibtaghā is derived from the infinitive form الابتغاء al-oibtigha", which means 'seek or ask' (p. 69). Moreover, Al-Taybii, cited in Al-Ainii (2001, vol.

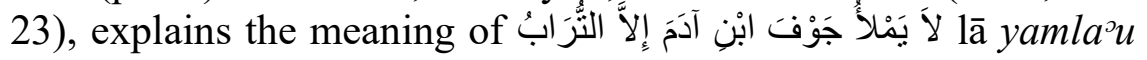
jawfa ${ }^{\circ}$ ibni ${ }^{\circ}$ adama ${ }^{\circ}$ illa al-turābu as 'nothing can satisfy whoever

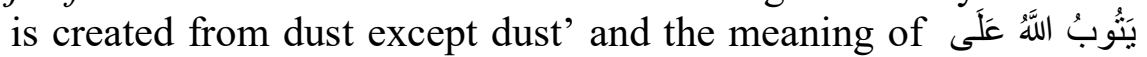
مَنْ نَابَ yatūbu Allahu calā man tāba as 'Allah accepts man's tawbah (repentance)’ (p. 70). Besides, Al-Ainii (2001, vol. 23) states that this issue is not related to dust itself, but rather it refers to 'death'. To put it differently, nothing can satisfy the eye, the belly or the mouth of mankind except dust of the grave (p. 69).

\section{Explaining Metonymy}

The phrase آِيْنِ آدَمَ obni adama is used in Arabic as a metonymy for the modified noun "every mankind" (Al-Ainii, 2001, vol. 23, p. 40).

\section{Assessment}

The translation is equally metonymic as the equivalent "the son of Adam" is used. Moreover, Khan (1997) uses a parenthetical statement (the human-being) to help the reader figure out the intended meaning.

Some Conditions are not Valid in Islamic Sharicah (laws).

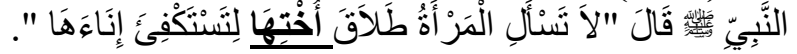


TRANSLATING Kināyah can mawșū f (METONYMY OF A MODIFIED OBJECT) IN SOME PROPHETIC HADITHS

Sahar Muhammed Ahmed Muhammed

مجلة وادي النيل للاراسات والبحوث الإنسانية والاجتماعية و التربوية (مجلة علمية محكمة)

E.g. 13 The Prophet said, "A Muslim woman shall not try to bring about the divorce of her sister (i.e. another Muslim woman) in order to take her place herself."(Conditions, Hadith 2723).

\section{Analysis and Context of Situation}

Ibn Hajar (vol. 5) terms some Hadiths in which this Hadith is involved as $\mathrm{Bab}$ "the conditions not permissible in marriage contract" (p. 323). Upon to this point, it is important to note that there are two types of conditions in the marriage contract. There are some valid conditions which may include a certain dowry; renting or even a woman can stipulate that her husband should not marry another woman, etc. These conditions are permissible and women can benefit from them. If one appoints some valid conditions for his wife, he is obliged to adhere to them (Ibn Hajar. Vol. 9, p. 218). On the contrary, other conditions are not valid in Islamic Sharicah (laws). According to Islamic laws, it is not permitted that a woman asks a man to divorce his wife so that she can marry him and can take the other wife's place and pleasure. In other words, stipulating the divorce of another woman is forbidden in Islam and a man is not obliged to fulfil this condition (Ibn Hajar, vol. 5, p. 323). Al-Ainii (2001, vol. 13) identifies that the word أخْنَهِا 'ukhtihā is used euphemistically to refer to 'a co-wife'. In general, it is used to refer to sister in Islam or in humanity (p. 427).

\section{Explaining Metonymy}

The word أَخْنَهِ $u k h t i h \bar{a}$ is a metonymy for a modified object 'another woman who is her sister in Islam or humanity' as the Prophet (P. B. U. H.) does not mean sister in the apparent meaning (p. 69). El-Zeiny (2005) translated Ibn Hajar's quotation (vol. 9) who further adds that the Prophet (P.B.U.H.) uses أُخْتِهَا "sensitize her to the fact that that woman is either her sister in Islam or humanity in the broad sense" (p. 246). 
مجلة وادي النيل للار اسات والبحوث الإسانية والاجتماعية والتربوية (مجلة علمية محكمة)

(ISSN : 2536 - 9555)

\section{Assessment}

The translator succeeds in conveying both metonymies in English through adopting a source-oriented strategy. Furthermore, he adds the direct meaning in a parenthetical statement to avoid any misunderstanding.

\section{Results}

The results of this study include the results of the written questionnaire. Table (1) shows these results, which identifies the percentages of successful and unsuccessful translation of the total numbers of metonymic expressions. The translator succeeded in rendering $5(38.5 \%)$ metonymic expressions of the total number of the metonymies of mofified objects at hand correctly and effectively, yet he failed at translating $3(23.2 \%)$ examples. Besides, there were $5(38.5 \%)$ metonymic expressions which needed further clarification through adding more modifications (footnotes, parentheses, explanation ...etc) in order not to confuse the TL readers and to render a precise meaning. Table (2) presents the assessment of translating metonymic expressions in Șaḥ̆h AlBukhārI and suggested translation.

Table 1

Percentages of Successful and unsuccessful Translation of All Metonymies of Modified Objects

\begin{tabular}{|c|c|c|}
\hline Total Number of Metonymies & $\mathbf{1 5}$ & Percentages \\
\hline Number of Successful Translation (S) & 5 & $38.5 \%$ \\
\hline Number of Unsuccessful Translation (U) & 3 & $23.2 \%$ \\
\hline $\begin{array}{c}\text { Number of Successful Translation which } \\
\text { Need Further Clarification }\end{array}$ & 5 & $38.5 \%$ \\
\hline
\end{tabular}


TRANSLATING Kināyah can mawșū f (METONYMY OF A MODIFIED OBJECT) IN SOME PROPHETIC HADITHS

Sahar Muhammed Ahmed Muhammed

\author{
مجلة وادي النيل للاراسات والبحوث الإنسانية والاجتماعية و التربوية (مجلة علمية محكمة)
}

Table 2

Metonymies of Modified Objects (Total 13)

\begin{tabular}{|c|c|c|c|c|}
\hline $\begin{array}{l}\text { Number of } \\
\text { Hadith } \\
\text { in Khan's } \\
\text { Translation } \\
\end{array}$ & $\begin{array}{l}\text { Translation of } \\
\text { the Metonymy }\end{array}$ & $\begin{array}{l}\text { Metonymic } \\
\text { Expression } \\
\text { in Arabic }\end{array}$ & $\begin{array}{l}\text { Assessment } \\
\text { of the } \\
\text { Translation }\end{array}$ & Suggested Translation \\
\hline $\begin{array}{l}\text { (1)Vol. } 1, \text { B. } 2 \\
\text { No. } 48\end{array}$ & $\begin{array}{l}\text { the shepherds of } \\
\text { black camels }\end{array}$ & رُعَاةُ الإِبِلِ الْبُهْجُ & $\begin{array}{l}\mathrm{S} \text { but needs } \\
\text { further } \\
\text { clarification }\end{array}$ & $\begin{array}{l}\ldots \text { the shepherds of (black) } \\
\text { camels }\end{array}$ \\
\hline $\begin{array}{l}\text { (2) Vol. } 4, \text { B. } \\
54 \text {, No. } 520\end{array}$ & $\begin{array}{c}\text { those Bedouins } \\
\text { who are busy } \\
\text { with their } \\
\text { camels } \\
\end{array}$ & أَهْلِ الْوَبَرِ & $\mathrm{U}$ & $\begin{array}{c}\text { people of mohair (Bedouins } \\
\text { who are busy with their } \\
\text { camels)... }\end{array}$ \\
\hline $\begin{array}{l}\text { (3) Vol. } 4, \text { B.52, } \\
\text { No. } 137\end{array}$ & $\begin{array}{l}\text { the slave of } \\
\text { Dinar and } \\
\text { Dirham and } \\
\text { Khamisa }\end{array}$ & 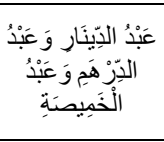 & $\begin{array}{l}\mathrm{S} \text { but needs } \\
\text { further } \\
\text { clarification }\end{array}$ & $\begin{array}{c}\text { the slave of Dinar and } \\
\text { Dirham (types of currency) } \\
\text { and khamisa (a black cloak } \\
\text { bordered with silk) }\end{array}$ \\
\hline $\begin{array}{l}\text { (4) Vol. } 3, \text { B. } \\
\text { 43, No. } 646\end{array}$ & $\begin{array}{l}\text { there is a reward } \\
\text { for serving any } \\
\text { animate (living } \\
\text { being) }\end{array}$ & 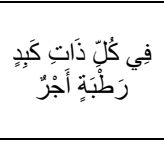 & $\mathrm{U}$ & $\begin{array}{l}\text { there is a reward for every } \\
\text { animate with moist liver } \\
\text { (for serving every living- } \\
\text { being) }\end{array}$ \\
\hline $\begin{array}{l}\text { (5) Vol. } 3, \text { B. } \\
\text { 46, No. } 713\end{array}$ & $\begin{array}{l}\text { as her Wala' } \\
\text { will be for the } \\
\text { one who pays } \\
\text { the price }\end{array}$ & 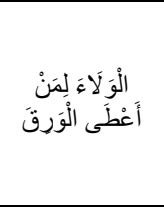 & $\mathrm{U}$ & $\begin{array}{l}\text { her wal } \bar{a}^{\supset} \text { (loyalty and } \\
\text { inheritance after death) is } \\
\text { for the one who gives the } \\
\text { silver (i.e. pays the price for } \\
\text { freeing/ manumitting a } \\
\text { slave) }\end{array}$ \\
\hline $\begin{array}{l}\text { (6) Vol. } 8, \text { B. } \\
76, \text { No. } 514\end{array}$ & $\begin{array}{l}\text { Who-ever loves } \\
\text { to meet Allah } \\
\ldots \text { who-ever } \\
\text { hates to meet } \\
\text { Allah }\end{array}$ & مَنْ كَرَّبَ لَلقَقَاءَاءَ اللَّهَ & $\begin{array}{l}\text { S but needs } \\
\text { further } \\
\text { clarification }\end{array}$ & $\begin{array}{l}\text {... whoever loves to meet } \\
\text { Allah (at the time of death } \\
\text { when being shown } \\
\text { glimpses of his approaching } \\
\text { destiny)... whoever hates to } \\
\text { meet Allah (at the time of } \\
\text { death when being shown } \\
\text { glimpses of his approaching } \\
\text { destiny) }\end{array}$ \\
\hline $\begin{array}{l}\text { (7) Vol. } 1, \text { B.3, } \\
\text { No. } 115\end{array}$ & $\begin{array}{l}\text { occupants of } \\
\text { these dwellings } \\
\text { (his wives) up } \\
\text { (for prayers) }\end{array}$ & صَوَاحِبَاتِ & $\mathrm{S}$ & \\
\hline $\begin{array}{l}\text { (8) Vol. } 8, \text { B. } \\
82, \text { No. } 799\end{array}$ & $\begin{array}{l}\text { (the chastity of) } \\
\text { what is between } \\
\text { his legs (i.e. his } \\
\text { private parts) }\end{array}$ & مَا بَيْنَ رِجْلَيْهِهِ & $\mathrm{S}$ & \\
\hline $\begin{array}{l}\text { (9) Vol. } 8, \text { B. } \\
82, \text { No. } 799\end{array}$ & $\begin{array}{l}\text { what is between } \\
\text { his jaws (i.e., } \\
\text { his tongue) }\end{array}$ & وَمَا بَيْنَ لَحْيَيْهِ & $\mathrm{S}$ & \\
\hline $\begin{array}{l}\text { (10) Vol. 4, B. } \\
\text { 55, No. } 583\end{array}$ & $\begin{array}{l}\text { the threshold of } \\
\text { the gate (of his } \\
\text { house). }\end{array}$ & عَتَبَةَة بَابِهِ & $\begin{array}{l}\text { S but needs } \\
\text { further } \\
\text { clarification }\end{array}$ & $\begin{array}{c}\text { The threshold of the gate of } \\
\text { his house (wife) }\end{array}$ \\
\hline
\end{tabular}


مجلة وادي النيل للاراسات والبحوث الإنسانية والاجتماعية والتربوية (مجلة علمية محكمة)

(ISSN : 2536 - 9555)

\begin{tabular}{|c|c|c|c|c|}
\hline $\begin{array}{l}\text { (11) Vol. 6, B. } \\
\text { 60, No. } 36\end{array}$ & $\begin{array}{c}\text { Then your } \\
\text { pillow is too } \\
\text { wide }\end{array}$ & إن لعريض إذا & $\begin{array}{l}\mathrm{S} \text { but needs } \\
\text { further } \\
\text { clarification }\end{array}$ & $\begin{array}{l}\text { Then your pillow (backside } \\
\text { of your head and neck) is } \\
\text { too wide if the white thread } \\
\text { (of dawn) and the black } \\
\text { thread (of the night) are } \\
\text { underneath your pillow }\end{array}$ \\
\hline $\begin{array}{l}\text { (12) Vol. 8, } \\
\text { B.76, No. } 444\end{array}$ & $\begin{array}{l}\text { the son of Adam } \\
\text { (the human } \\
\text { being) }\end{array}$ & لِالِنبن آدََّ & S & \\
\hline $\begin{array}{l}\text { (13), Vol. 3, B. } \\
\text { 50, No. } 884\end{array}$ & $\begin{array}{l}\text { her sister (i.e. } \\
\text { another Muslim } \\
\text { woman) }\end{array}$ & أُخْتِهَا & $\mathbf{S}$ & \\
\hline
\end{tabular}

\section{Discussion}

The first research question addresses the frequency of use of Toury's strategies in translating the selected metonymies in the Prophetic Hadiths. The results showed that source-orientedness was the most frequently used strategy in translating the metonymic expressions. The translator used this strategy in translating 11 metonymic expressions out of 13 expressions. This is because this research deals with a religious text and it is necessary to preserve its unique features and render its highly figurative style to the TL readers.

The second research question of the study aimed to determine which translation strategy can be regarded as the best and most effective strategy in conveying culture-specific items in Prophetic Hadiths. The overall outcomes of the current study suggest source-oriented translation for rendering metonymy in the Prophetic Hadith for various reasons. The goal of source-oriented strategy is to preserve the original flavour and the essence of the SL. Additionally, it profounds the SL cultural input; in turn, exchanging cultures may happen. Thus, the resulted text breaks the conventions of the TL which is suitable for enriching language translation expression. These goals are suitable for rendering rich text such as the Prophetic Hadiths.

As far as Hadith translation is concerned, it is important to shed light on translating cultural-specific items, CSIs, which is considered a crucial issue in theory and practice in Translation 
TRANSLATING Kināyah can mawșū f (METONYMY OF A MODIFIED OBJECT) IN SOME PROPHETIC HADITHS

Sahar Muhammed Ahmed Muhammed

مجلة وادي النيل للاراسات والبحوث الإنسانية والاجتماعية والتربوية (مجلة علمية محكمة)

Studies, in order to render the cultural input to refer to the TL readers. This is because transferring CSIs from one language into another pose a challenging task to translators. In this respect, Tawfik (2007) refers to the use of transliteration in order to overcome the problems of translating these CSIs. The use of this strategy raises the importance of using footnotes or parentheses. In the light of this discussion, there are various examples of CSIs in the Hadiths at hand, e.g.الدر هم، الدينار، الخميصة وو لاء العتق. These CSIs seem vague for TL readers. As a result, the researcher has suggested the use of transliteration, followed by footnotes or parentheses to identify the exact meanings of these words and not to confuse the TL readers.

\section{Conclusion}

Metonymy is one of the most sensitive areas that translators encounter while rendering religious texts. Whenever there is a problem in rendering the metonymic meaning of a particular word or any linguistic unit, it is well- advised for translators to try to observe the highly figurative style of the Prophetic sayings in order not to sacrifice part of the meaning. However, if transferring such figures would negatively affect the TL comprehensibility, translators should use footnotes, parentheses, or any other way whenever necessary. This is why this study suggests sourceoriented translation for rendering metonymy in the Prophetic Hadith.

\section{References}

Abbasi, G., Saleh zadeh, S., Janfaza, E., Assemi, A. \& Dehghan, S.S. (2012). Language, Translation, and Culture. International Conference on Language, Medias and Culture IPEDR (33) pp. 83-87.

Abdul-Raouf, H. (2006). Arabic Rhetoric: A Pragmatic Analysis. London \& New York: Routledge Taylor \& Francis Group. 


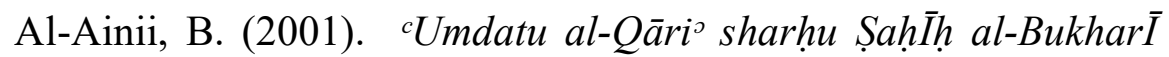
(The Mayor of the Continental Explained Sahih Bukhari). Beirut: Dāru al-Kutubi al- cIlmayati.

Al-Jurjani, Al-Sharif (n.d.). Al-Tacri If $\bar{a} t$ (The Definitions). Iraq: Dāru Al-Shshu’ūni Al-ththaqāfilati al-cāmmati.

Al-Kirmany, M. (1981). Al- kawākibu al-Darāri $\bar{I} \bar{I}$ sharḥi Șaḥ̆ḥh Al-Bukhār $\bar{I}$ (Al-Darari Planets in Explaining Sahih AlBukhari /Explanation of Al-Kirmani on Al-Bukhari).Beirut:

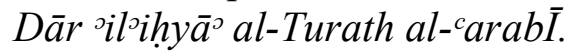

Al-Mucjam al-Wasİt (2004). International Sharūk Bookshop (4 ${ }^{\text {th }}$ ed.). Retrieved May 15, 2019 from http://www.waqfeya.com/book.php?bid=210

Al-Munajjid, M. (2014). How He Treated Them? Zad Group Publishing, Riyadh.

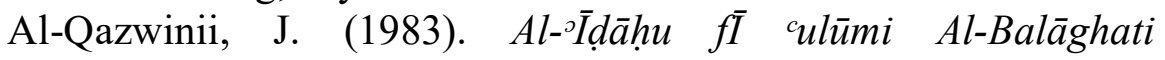
(Clarification of the Sciences of Rhetoric). Edited by AbdulMunam Khafaji. Beirut.

Al-Sakkaki, A. (1937). Miftāhu al-c Ulümi (Key of the Sciences]. Cairo: Al-BābI Al-Halabİ.

American Psychological Association (6 $6^{\text {th }}$ ed.). Publication Manual of the American Psychological Association. Washington, DC.

Brdar, M. \& Brdar-Szabo, R.(2014). Metonymies we (don't) translate: The Case of Complex Metonymy. Argumentum, 10, pp. 232-247.

Bunnduq, M. (1996). Al-Madkhalu fī cilmi al-Bayāni (An Introduction to the Art of Tropes). Cairo: Dāru Zahrā̃u $A L$ sharqi.

El-Zeiny, N. (2005). Translating Euphemism in Prophetic Hadith. In Cairo Studies in English (CSE) (pp.: 217- 304). Cairo: Cairo University, Faculty of Arts.

Faraj, F. M. (2002). Al-Kināyatu fī Al-Balāghati Al-carabayati (Metonymy in the Arabic Language). Cairo: Mașr llkhadamāti alcilmayati.

Farid, A. H. (1998). Al-Kināyatu wal-Tacr $\bar{I} d$ (Metonymy and an Indirect Intimation). Cairo: Dār Qib $\bar{a}^{\circ}$ llțibāa ati wal-nashri wal-tawz $\bar{I}^{c}$. 
TRANSLATING Kināyah can mawșūf (METONYMY OF A MODIFIED OBJECT) IN SOME PROPHETIC HADITHS

Sahar Muhammed Ahmed Muhammed

مجلة وادي النيل للاراسات والبحوث الإسانية والاجتماعية والتربوية (مجلة علمية محكمة)

Hijazi, M.M. (1986). Al-Kināyah fi al-Hadith al-Nabawy AshSharİf wa 'atharuhā al-Balāghi min Khilāl Șaḥ̆h Al-BukhārI (Metonymy in the Prophetic Hadith and its impact on rhetoric in Șah̆ḥ Al-Bukhārl̄ (Unpublished Ph.D. Thesis). Cairo: AlAzhar University, Faculty of Arabic Language.

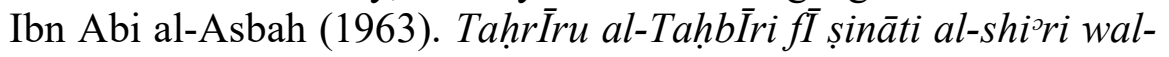
nathri wabayāni iciāzi al-Qur'ani (Editing of Writing in the Poetry and Prose Industry and Explaining the Miracle of the Qur'an). Edited by Hefny Muhammed Sharaf. Cairo: lajnatu `ihyā̃u al-turathi al-`islāmI.

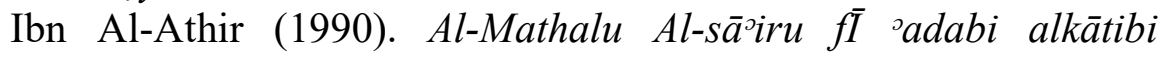
walshāri (Common Proverb in the Work of the Writer and Poet). Edited by Muhammed Mohie El-Din Abdul Hamid. Beirut: Al-Maktabatu Al-cașrayatu.

Ibn Hajar, Ahmad Ibn ${ }^{\mathrm{C} A l i}$ Ibn Muḥammed Al-cAsqalānĪ (n.d.). Fath al-BārI (Gift of the Maker]. Beirut: Dāru al-Macrifati.

Ibn Manzur, J. (n.d.). Lissānu al-c Arabi (The Arab Tongue]. Cairo: Dāru al-Macārifi.

Khan, M. M. (1997). The Translation of the Meanings of Saḥ̆h AlBukhārĪ: Arabic-English. Saudi-Arabia: Darussalam.

Khan, M.M \& Hilali, M.T. (1996). The Translation of the Meanings of the Quran. Saudi-Arabia: Maktabat Darussalam.

Larcher, P. (2013). Arabic Linguistic Tradition I I: Pragmatics. In Jonathan Owens (Eds.), The Oxford Handbook of Arabic Linguistics (pp. 185-212). New York \& London: Oxford University Press.

Mahdi, A. (2009). Metonymy in English and Arabic. Journal of Al- Qadisiya University, 12 (1), pp.:7-20.

Muhammad, A. (2017). Translating Metonymy in the Holy Qur'an: Surat An-Nisa as a Case Study (Unpublished M.A. Thesis). United Arab Emirates: American University of Sharjah, College of Arts and Sciences.

Tabana, B. (1988). Mucjamu al-Balāghati al-ćArabiyyati (Lexicon of Arabic Rhetoric). Jeddah: Dāru al-Manarati lil-Nashri wat-tawz $\bar{I} c i$. 


\section{مجلة وادي النيل للاراسات والبحوث الإنسانية والاجتماعية والتربوية (مجلة علمية محكمة)}

(ISSN : 2536 - 9555)

Toury, G. (1980). Translated Literature; System, Norm, Performance: Toward A TT-Oriented Approach to Literary Translation. Poetics Today, 2 (4), pp.: 9-27.

---------. (1995). Descriptive Translation Studies and Beyond. Amsterdam/ Philadelphia: John Benjamins Publishing Group.

Wahbah, M. \& al-Muhandis, k. (1984). Mucjam al-Mustalahat al'Arabiyah fi al-Lughah $w$ al- ${ }^{\circ}$ Adab' (Lexicon of Arabic Terms in Language and Literature] $\left(2^{\text {nd }}\right.$ Ed.). Beirut: Lebanese Bookshop.

Zheng, H. (2014). On Metonymy and Its Translation. World Journal of English Language, 4(4), 29-33. 